(RESEARCh ARTICLE)

\title{
Study of the effect of process parameters on the yield of fermentable sugar from red cocoyam (Xanthosoma sagittifolium) peels via acid and enzyme hydrolysis
}

\author{
Onoh Ikechukwu Maxwell ${ }^{1,}{ }^{*}$, Anho Lawrence Oghenerivwe ${ }^{1}$ and Egwuagu Onyekachi ${ }^{2}$ \\ ${ }^{1}$ Chemical Engineering Department, Enugu State University of Science \& Technology, ESUT, Nigeria. \\ ${ }^{2}$ Mechanical Engineering Department, Enugu State University of Science \& Technology, ESUT, Nigeria.
}

International Journal of Frontiers in Engineering and Technology Research, 2021, 01(01), 061-069

Publication history: Received on 07 April 2021; revised on 10 May 2021; accepted on 12 May 2021

Article DOI: https://doi.org/10.53294/ijfetr.2021.1.1.0047

\begin{abstract}
The aim of this work is to study the acid and enzymatic hydrolysis of cocoyam peels using $\mathrm{HCl}_{2} \mathrm{H}_{2} \mathrm{SO}_{4}$ acids and cellulase enzyme. The cellulase was secreted from Aspergillus Niger (A. niger) fungi. The proximate analysis of the substrate showed that cocoyam peel is a lignocellulosic biomass with a cellulose composition of $48 \%$. The effect of the process parameters (time, temperature, acid concentration and $\mathrm{pH}$ ) on the yield of glucose in acid and enzymatic hydrolysis of the cocoyam peel was respectively investigated. Maximum glucose yield of $44.5 \%$ was obtained after 3 days of enzymatic hydrolysis at $30^{\circ} \mathrm{C}$ and $\mathrm{pH}$. The $\mathrm{HCl}$ acid hydrolysis showed a maximum glucose yield of $27.3 \%$ at $70^{\circ} \mathrm{C}, 5 \%$ $\mathrm{HCl}$ after 180 minutes. The glucose yield in $\mathrm{H}_{2} \mathrm{SO}_{4}$ hydrolysis was relatively lower than that of the $\mathrm{HCl}$ with a maximum yield of $26.5 \%$ at $70^{\circ} \mathrm{C}, 5 \% \mathrm{H}_{2} \mathrm{SO}_{4}$ after 180 minutes. In addition to, the functional groups present in the glucose synthesized from cocoyam ground peels and the standard glucose were evaluated using Fourier Transformed Infrared (FTIR). The FTIR results showed similarities in the functional groups present in both sugars. Cocoyam peel can be used for the production of glucose and further fermentative process to produce ethanol.
\end{abstract}

Keywords: Acid hydrolysis; Enzyme hydrolysis; Glucose; pH; Temperature

\section{Introduction}

In years passed, increasing research and development efforts have been directed to reducing the use of fossil fuels and decreasing the emission of carbon dioxide. Bio-ethanol is made mostly from sugar cane, maize, wheat, and barley. However, the use of these crops to produce bio-ethanol competes with their use as food sources (Searchinger et al., 2008). Hence, a special attention is actually being paid to the use of renewable resources, which are mainly agricultural and industrial by-products. Examples of the agricultural wastes are (corn stover, sugar cane bagasse, yam, cocoyam, flux straw, potato pulp, cassava bagasse, cowpea husk, rice husk, soya bean husk), forestry (beech bark, beech wood, populous tremuloides wood) and herbaceous materials (e.g. reed grass, switch grass, rye grass). These agricultural wastes biomass tend to dominate and pollute the environment. Many of these agro-wastes are allowed to rot away and not utilized (Obot et al., 2008). These wastes biomass consist of cellulose, hemicelluloses, lignin and other materials called extractive, (Ghose, 1956; Aberuagba, 1997). Among all the constituents of agricultural waste biomass, cellulose constitutes relative high percentage, because it is a strong elastic material that forms cell wall of nearly all plants, (Aberuagba, 1997). The cellulose can be hydrolyzed to produce glucose for human needs which can be used as substrates for fermentative production of useful product like alcohols, (John et al., 2007; Benkum et al., 2008). As mentioned above, all forms of plant materials that can be used for energy are derived from agricultural waste (Soltoes, 1983; Barnard \& Kristoferson, 1983; Enweremadu, 2004).

\footnotetext{
${ }^{*}$ Corresponding author: Onoh Ikechukwu Maxwell

Chemical Engineering Department, Enugu State University of Science \& Technology, ESUT, Nigeria.
} 
Cocoyam is the third most important root crops (after yam and cassava) cultivated in West Africa. More than three quarters of world cocoyam production comes from Africa with Nigeria and Ghana being the world's leading producers (Onwueme, 1982). In Egypt, Hawaii and Japan they are also important crops, (Iwuoha et al., 1995). In general, they are stem tubers that are widely cultivated in both tropical and subtropical regions of the world, (Purseglove, 1972). Among the seven species of the colocasia (Taro) which originated from Asia and about forty species of xanthosoma (Tannia) which is from America, the two species mostly grown in West Africa particularly in Nigeria are the Colocasia Esculenta and Xanthosoma Sagittifolium, which are either red or white, (Purseglove, 1972).

The Xanthosoma Sagittifolium variety in Nigeria is hard and highly starchy which makes it very easily used for fufu preparation. While Colocasia Esculenta, with a soft tuber is usually prepared and eaten like yam. The young leaves and the cormels of the Colocasia esculenta variety serve as leafy vegetables in some diets, in Nigeria, (Ihekoronye, 1985). The substrate used in this study is Xanthosoma sagittifolium (red cocoyam). Xanthosoma sagittifolium can be processed in several ways to produce food and feed products similar to that of potatoes in the Western world. Cocoyam can be processed via the following; boiling, roasting, frying, milling and conversion to "fufu", as earlier mentioned, soup thickeners, flour for baking, chips, beverage powder, porridge and speciality of food for gastrointestinal disorder (Ihekoronye, 1985; Onwueme, 1978; Hussain, 1984; Obiechina, 1985).

Saccharification of cocoyam peels to produce reducing sugar is important, owing to the fact that reducing sugars are essential raw material for the production of bio-ethanol (bio-fuel). Saccharification is basically achieved via acidic and enzymatic hydrolysis of polysaccharides or cellulose. The Large quantities of these wastes produced annually in Nigeria are under-utilized. The practice is usually, to leave residues to decomposed or burnt. However, studies have shown that these residues could be processed into liquid fuels or combusted/gasified to produce electricity and heat (Soltoes, 1983; Barnard \& Kristoferson, 1983; Enweremadu, 2004). Conversion of these waste products such as glucose, xylose, arabinose, etc. provides a more efficient means of waste management.

This study therefore, focused on the production of bioethanol from cocoyam peels that are readily available in the country in large quantities as agrowastes. The use of waste biomass like cocoyam peel to generate energy can reduce problems associated with waste management such as pollution, greenhouse gaseous emissions and fossil fuels use. The rate of global warming can be reduced drastically through the use of bioenergy derived from municipal or agricultural wastes. According to a recent past report, it was proposed that by the year 2020, constant use of biomass will produce 19 million tons of petroleum equivalents. Out of this, $46 \%$ will be obtained from bio-wastes like farm waste, agricultural waste, municipal solid waste and other biodegradable waste (Xavier, 2007).

\section{Material and methods}

\subsection{Acid hydrolysis of Cocoyam peel}

The cocoyam peels were collected and pretreated by washing, drying in an oven at $105^{\circ} \mathrm{C}$ for 4 hours and grinding before sieving to fine particle size of $250 \mu \mathrm{m}$. Thereafter, the dilute acid hydrolysis was carried out using the method adopted and described by Lenihan et al., (2010) and Kelly et al., (2014). The ground cocoyam peels were first soaked in ethanol for $24 \mathrm{hrs}$ after which they were washed repeatedly with distilled water until the residues were free of the solvent. $1.0 \mathrm{~g}$ of the pretreated biomass was weighed into a $250 \mathrm{~mL}$ conical flask. $20 \mathrm{~mL}$ of $1 \% \mathrm{HCl}(0.1 \mathrm{M})$ was added into the flask. The flask was covered with cotton wool and aluminum foil and put into a water bath set at $30^{\circ} \mathrm{C}$ for 30 minutes. The mixture was thereafter filtered with filter paper, neutralized with drops of $6 \mathrm{M} \mathrm{NaOH}$ and the concentration of the simple sugar obtained was measured using DNS method. The experiment was repeated at different concentrations of $\mathrm{HCl}(3 \%$ and $5 \%)$ for different durations $\left(60,90,120,150,180\right.$ minutes) and at different temperatures $\left(50^{\circ} \mathrm{C}\right.$ and $\left.70{ }^{\circ} \mathrm{C}\right)$. $\mathrm{H}_{2} \mathrm{SO}_{4}$ at different concentrations of $(1 \%, 3 \%, 5 \%)$ for duration $(60,90,120,150,180$ minutes $)$ and at temperatures $\left(30^{\circ} \mathrm{C}, 50^{\circ} \mathrm{C}\right.$ and $\left.70^{\circ} \mathrm{C}\right)$ was also used for the experiment. The yield of simple sugar (glucose) was calculated using Equations 2.1 and 2.2, while the percentage conversion of cellulose/ hemicelluloses to simple sugars at each run was calculated using Equation 2.3 as described by Kelly et al., (2014).

$$
\begin{gathered}
\text { yield }(\%)=\frac{M_{\text {glucose }}}{M_{\text {initial }}} \times 100 \\
M_{\text {glucose }}(g)=\text { Vol }_{\text {Hydrolysate }} \times \text { Conc }_{\text {glucose }}(g / 100 \mathrm{ml}) \\
E(\%)=\frac{M_{\text {glucose }} \times f}{M_{\text {initial }} \times y} \times 100
\end{gathered}
$$


Where

yield $(\%)=$ yield of simple sugar (glucose) based on the total weight of the biomass

$M_{\text {glucose }}(g)=$ total mass of simple sugar (glucose) after hydrolysis

Vol $_{\text {hydrolysate }}=$ total volume of the hydrolysis mixture $(\mathrm{mL})$

Conc $_{\text {glucose }}=$ percentage concentration of simple sugar (glucose) obtained from the standard graph

$E(\%)=$ simple sugar (glucose) percentage conversion

$M_{\text {Initial }}=$ mass of the extractive free biomass

$F=$ conversion factor $(0.9$ for cellulose $)$

$y=$ fraction of cellulose /hemicelluloses in the biomass

\subsection{Cellulase synthesis and Enzyme assay}

\subsubsection{Isolation of Aspergillus Niger}

The fungi Aspergillus Niger (A. niger) was isolated and characterized at Microbiology Department of Enugu State University of Science and technology (ESUT) Nigeria following the method described by Akida et al., (2015). Soil obtained from groundnut husk dump site was crushed, sieved and diluted serially using sterile distilled water. Different dilutions of the soil was inoculated on the surface of slant Potato Dextrose Agar (PDA) medium in test tubes and incubated for 7 days. Spores of A. niger were harvested by vortex. Cellulase production was detected by the disappearance of the red colour of the Congo red solution around microbial colonies. Evaluation of the clear zones of each colony was estimated as radius $(\mathrm{mm})$ of the clear zone minus the radius of the colony. A. niger colonies producing large clear zones were picked up (Omojashola \& Jilani, 2009).

\subsubsection{Inoculums preparation}

Inoculums for enzyme production were prepared by adding $10 \mathrm{~mL}$ of citrate buffer (pH of 5.0) to each test tube containing fully grown spores of $A$. niger. The inoculums were estimated to have $2.8 \times 10^{6} \mathrm{spores} / \mathrm{ml}$ (Omojashola \& Jilani, 2009). The inoculums were stored in a refrigerator for future use.

\subsubsection{Cellulase enzyme production}

Enzymes production was carried out in $250 \mathrm{~mL}$ Erlenmeyer flasks with $50 \mathrm{~mL}$ medium as described by (Fang et al., 2010). The ingredients of culture medium included $30 \mathrm{~g} / \mathrm{L}$ alkaline pretreated cocoyam shell (dry biomass), $1 \mathrm{~g} / \mathrm{L}$ glucose, $6 \mathrm{~g} / \mathrm{L}$ ammonium sulfate, $2.0 \mathrm{~g} / \mathrm{L} \mathrm{KH}_{2} \mathrm{PO}_{4}, 0.3 \mathrm{~g} / \mathrm{L} \mathrm{CaCl}_{2}, 0.3 \mathrm{~g} / \mathrm{L} \mathrm{MgSO}_{4}, 0.005 \mathrm{~g} / \mathrm{L} \mathrm{FeSO}_{4}, 0.0016 \mathrm{~g} / \mathrm{L} \mathrm{MnSO}_{4}$, $0.0014 \mathrm{~g} / \mathrm{L} \mathrm{ZnSO}_{4}$ and $0.0037 \mathrm{~g} / \mathrm{L} \mathrm{CoCl}_{2}$. The initial $\mathrm{pH}$ value was adjusted to 4.8 by adding $2.5 \mathrm{~mL}$ citrate buffer solution $(1 \mathrm{~mol} / \mathrm{L})$ to the medium. Then the prepared medium was autoclaved at $121^{\circ} \mathrm{C}$ for $30 \mathrm{~min}$. The submerged fermentation started by inoculating the $50 \mathrm{~mL}$ medium with $10 \mathrm{ml}$ of the fungi inoculums in a $250 \mathrm{~mL}$ Erlenmeyer flask. The flask was incubated under shaker for 7 days. The fermentation was terminated when the glucose level was zero. The medium was filtered and centrifuged to obtain the supernatant, which is referred to as the crude enzyme.

Cellulase assay was done following the procedure described by Mandels (2005). One milliliter of 1\% Carboxyl Methyl Cellulose (CMC) in $0.1 \mathrm{M}$ citrate suffer $(\mathrm{pH} 5.5)$ was placed in a test tube and $1 \mathrm{ml}$ of culture filtrate was added. The reaction mixture was incubated at $50^{\circ} \mathrm{C}$ for $30 \mathrm{mins}$ and the reaction terminated by adding $1.5 \mathrm{ml}$ of DNS reagent. The tubes were heated at $100^{\circ} \mathrm{C}$ in a boiling water bath for 15 minutes and then cooled at room temperature. The absorbance was read at $540 \mathrm{~nm}$. Enzyme activity is expressed as mmol glucose released per sec ml of culture filtrate. The result after 7 days of incubation gave $2.4 \times 10^{-4} \mu \mathrm{g} / \mathrm{ml}$.

\subsection{Enzymatic hydrolysis}

The enzymatic hydrolysis was performed in $250 \mathrm{~mL}$ Erlenmeyer flasks with a $20 \mathrm{~mL}$ mixture of $0.05 \mathrm{M}$ citrate buffer solution ( $\mathrm{pH}$ 5.0), and enzymes. $1 \mathrm{~g}$ of the alkaline $(\mathrm{NaOH})$ pretreated ground cocoyam peels was added in the mixture and the flask was incubated in an orbital shaker $(140 \mathrm{rpm})$ at $30^{\circ} \mathrm{C}$ (Fang et al., 2010). Sampling was conducted at 1 day interval for analysis. The glucose yield was analyzed using the DNS method. The different pH used for the hydrolysis 
process was 3.0, 5.0 and 7.0. The $\mathrm{pH}$ was adjusted using citrate buffer and the temperatures used were 30,50 and $70^{\circ} \mathrm{C}$ (Lisa et al., 2012)

\subsection{Dinitro-salicylic (DNS) method of simple sugar analysis (Miller, 1959)}

Dinitro-salicylic acid reagent solution, $1 \%$

- $\quad$ Dinitro-salicylic acid: $10 \mathrm{~g}$

- $\quad$ Phenol: 2 g (optional, see Note 1)

- $\quad$ Sodium sulfite: $0.5 \mathrm{~g}$

- $\quad$ Sodium hydroxide: $10 \mathrm{~g}$

- $\quad$ Potassium sodium tartrate solution, $40 \%$

\subsubsection{Procedure}

- Add $3 \mathrm{ml}$ of DNS reagent to $3 \mathrm{ml}$ of glucose sample in a lightly capped test tube. (To avoid the loss of liquid due to evaporation, cover the test tube with a piece of paraffin film if a plain test tube is used.)

- Heat the mixture at 90 $\mathrm{C}$ for 5-15 minutes to develop the red-brown color.

- Add $1 \mathrm{ml}$ of a $40 \%$ potassium sodium tartrate (Rochelle salt) solution to stabilize the color.

- After cooling to room temperature in a cold water bath, the absorbance was recorded with a spectrophotometer at $540 \mathrm{~nm}$

Note1: Phenol, up to $2 \mathrm{~g} / \mathrm{l}$, intensifies the color density. It changes the slope of the calibration curve of absorbance versus glucose concentration but does not affect the linearity. The above procedure yield an absorbance of 1 for $1 \mathrm{~g} / \mathrm{l}$ of glucose in the original sample in the absence of phenol in the reagent, as opposed to an absorbance of $2.5 \mathrm{for} 1 \mathrm{~g} / \mathrm{l}$ of glucose in $2 \mathrm{~g} / \mathrm{l}$ of phenol. This property can be exploited to achieve the maximum sensitivity for dilute samples. See Fig 1 at for the glucose standard graph.

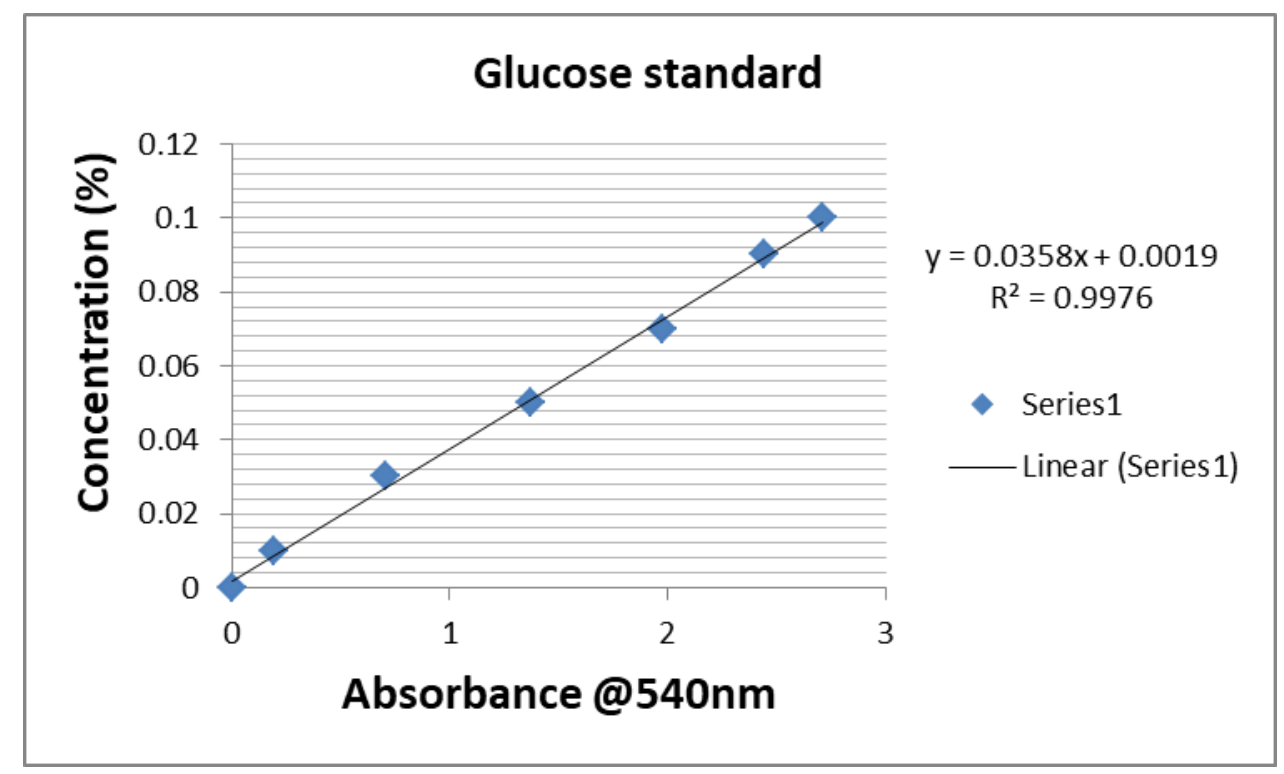

Figure 1 Glucose standard graph of concentration against absorbance

\section{Results and discussion}

The results obtained for the study of the effects of time, acid type/concentration and temperature on glucose yield for acid hydrolysis of coco yam ground peels are shown on Tables 3.1, 3.2, and 3.3 below. It was observed that glucose yield 
for $\mathrm{HCl}$ hydrolysis was higher than that of $\mathrm{H}_{2} \mathrm{SO}_{4}$ hydrolysis. At high temperature and acid concentration, higher glucose yield is achieved faster than at low temperature and low acid concentration (Kelley et al., 2014; Ye and Cheng, 2002).

However, the result showed a maximum sugar yield of $27.3 \%$ and $26.5 \%$ for $5 \% \mathrm{HCl}$ and $5 \% \mathrm{H}_{2} \mathrm{SO}_{4}$ hydrolysis respectively at $70^{\circ} \mathrm{C}$ and at 180 minutes. This result trend was in consonance with results obtained in similar studies of acid hydrolysis of lignocellulosic biomass from literatures. Increase in contact time and increase in acid concentration will enhance adequate access of the acid molecules to the cellulose content of a lignocellulosic biomass, and thus, break adequately the crystalline bonds (hydrogen bonds) of the cellulose polymer into glucose monomers, thereby leading to higher glucose yield. Ye and Cheng (2002) in their study reported higher glucose yield at higher temperature.

Table 1 Percentage glucose yield with different acids and varying acid concentrations at $30^{\circ} \mathrm{C}$.

\begin{tabular}{|c|c|c|c|c|c|c|}
\hline \multicolumn{7}{|c|}{ At $\mathbf{3 0}$ C } \\
\hline $\begin{array}{c}\text { Time } \\
\text { (hrs) }\end{array}$ & $\begin{array}{c}\mathbf{1 \%} \text { HCl } \\
\% \text { glucose }\end{array}$ & $\begin{array}{c}\mathbf{1 \%} \mathbf{H}_{2} \mathbf{S O}_{4} \\
\% \text { glucose }\end{array}$ & $\begin{array}{c}\mathbf{3 \%} \mathbf{H C l} \\
\% \text { glucose }\end{array}$ & $\begin{array}{c}\mathbf{3 \%} \mathbf{H}_{2} \mathbf{S O}_{4} \\
\% \text { glucose }\end{array}$ & $\begin{array}{c}\mathbf{5 \%} \mathbf{~ H C l} \\
\% \text { glucose }\end{array}$ & $\begin{array}{c}\mathbf{5 \%}_{\mathbf{~}} \mathbf{H O}_{4} \\
\% \text { glucose }\end{array}$ \\
\hline 0 & 0 & 0 & 0 & 0 & 0 & 0 \\
\hline 30 & 0.5 & 0.5 & 1.1 & 0.8 & 2.2 & 1.4 \\
\hline 60 & 1.4 & 0.9 & 1.6 & 1.9 & 2.9 & 3 \\
\hline 90 & 1.75 & 1.2 & 2.1 & 2.3 & 3.4 & 3.4 \\
\hline 120 & 2.1 & 1.5 & 2.6 & 2.7 & 3.9 & 3.8 \\
\hline 150 & 2.6 & 1.95 & 3.5 & 3.4 & 5.45 & 5 \\
\hline 180 & 3.1 & 2.4 & 4.4 & 4.1 & 7 & 6.2 \\
\hline
\end{tabular}

Table 2 Percentage glucose yield with different acids and varying acid concentrations at $50^{\circ} \mathrm{C}$

\begin{tabular}{|c|c|c|c|c|c|c|}
\hline \multicolumn{7}{|c|}{ At $50^{\circ} \mathrm{C}$} \\
\hline $\begin{array}{l}\text { Time } \\
\text { (hrs) }\end{array}$ & $\begin{array}{c}\mathbf{1 \%} \mathbf{H C l} \\
\% \text { glucose }\end{array}$ & $\begin{array}{l}\mathbf{1 \% ~ H}_{2} \mathrm{SO}_{4} \\
\% \text { glucose }\end{array}$ & $\begin{array}{c}\mathbf{3 \%} \mathbf{H C l} \\
\% \text { glucose }\end{array}$ & $\begin{array}{l}\mathbf{3 \%} \mathrm{H}_{2} \mathrm{SO}_{4} \\
\% \text { glucose }\end{array}$ & $\begin{array}{c}\mathbf{5 \%} \mathbf{H C l} \\
\% \text { glucose }\end{array}$ & $\begin{array}{l}5 \% \mathbf{H}_{2} \mathrm{SO}_{4} \\
\% \text { glucose }\end{array}$ \\
\hline 0 & 0 & 0 & 0 & 0 & 0 & 0 \\
\hline 30 & 1.2 & 1.1 & 2.3 & 1.8 & 2.1 & 2.8 \\
\hline 60 & 2.3 & 2.2 & 3.8 & 3.6 & 5.1 & 3.6 \\
\hline 90 & 3.65 & 3.25 & 5 & 4.95 & 7 & 5.5 \\
\hline 120 & 5 & 4.3 & 6.2 & 6.3 & 8.9 & 7.4 \\
\hline 150 & 5.9 & 5.1 & 7.8 & 7.45 & 10.1 & 9 \\
\hline 180 & 6.8 & 5.9 & 9.4 & 8.6 & 11.3 & 10.6 \\
\hline
\end{tabular}

In the study of the effects of process parameters (time, $\mathrm{pH}$ and temperature) on the yield of glucose via enzymatic hydrolysis, the results as presented on Table 4 showed the maximum glucose yield of $44.5 \%$ obtained at $30^{\circ} \mathrm{C}$ at $\mathrm{pH}$ of 5 and 72 hours ( 3 days). The table also contains the conversion efficiency (E) based on the total concentration of cellulose and hemicelluloses in the cocoyam peel.

The yield of glucose was observed to decrease as the temperature increased from 30 to $70^{\circ} \mathrm{C}$. Gautam et al., (2011) in their study reported an optimum pH range of 5-6 for cellulase activity and at $40^{\circ} \mathrm{C}$. Also, Nermeen et al., (2010) reported an optimum $\mathrm{pH}$ range of 5.5-7 and $45^{\circ} \mathrm{C}$ for cellulase activity. The results obtained in this study were in agreement with 
the results of similar studies from the literatures. The yield of glucose from enzymatic hydrolysis of the cocoyam peels actually depends on process parameters investigated.

Table 3 Percentage glucose yield with different acids and varying acid concentrations at $70^{\circ} \mathrm{C}$

\begin{tabular}{|c|c|c|c|c|c|c|}
\hline \multicolumn{7}{|c|}{ At 70 } \\
\hline $\begin{array}{c}\text { Time } \\
\text { (hrs) }\end{array}$ & $\begin{array}{c}\mathbf{1 \%} \text { HCl } \\
\% \text { glucose }\end{array}$ & $\begin{array}{c}\mathbf{1 \%}_{\mathbf{2}} \mathbf{S O}_{\mathbf{4}} \\
\% \text { glucose }\end{array}$ & $\begin{array}{c}\mathbf{3 \%} \mathbf{H C l} \\
\% \text { glucose }\end{array}$ & $\begin{array}{c}\mathbf{3 \%}_{\mathbf{2}} \mathbf{S O}_{\mathbf{4}} \\
\% \text { glucose }\end{array}$ & $\begin{array}{c}\mathbf{5 \%} \mathbf{~ H C l} \\
\% \text { glucose }\end{array}$ & $\begin{array}{c}\mathbf{5 \%}_{\mathbf{2}} \mathbf{S O}_{\mathbf{4}} \\
\% \text { glucose }\end{array}$ \\
\hline 0 & 0 & 0 & 0 & 0 & 0 & 0 \\
\hline 30 & 2.1 & 1.97 & 3.99 & 2.93 & 5.72 & 5.373 \\
\hline 60 & 4.1 & 3.5 & 5.8 & 5.67 & 14.2 & 11.421 \\
\hline 90 & 5.75 & 4.9 & 8.41 & 8.31 & 19.15 & 15.7705 \\
\hline 120 & 7.4 & 6.3 & 11.02 & 10.95 & 24.1 & 20.12 \\
\hline 150 & 8.71 & 7.695 & 13.11 & 12.775 & 25.7 & 23.31 \\
\hline 180 & 10.02 & 9.09 & 15.2 & 14.6 & 27.3 & 26.5 \\
\hline
\end{tabular}

Table 4 The Effect of pH, Time and Temperature on the Percentage Yield of Glucose in Enzymatic Hydrolysis

\begin{tabular}{|c|c|c|c|c|c|c|c|}
\hline \multirow{2}{*}{ Temp. } & Time & \multicolumn{2}{|c|}{ pH 3 } & \multicolumn{2}{c|}{ pH 5 } & \multicolumn{2}{c|}{ pH 7 } \\
\hline \multirow{2}{*}{$\left.{ }^{\circ} \mathbf{C}\right)$} & (hour) & $\begin{array}{c}\text { Yield } \\
\text { (\%) }\end{array}$ & E (\%) & $\begin{array}{c}\text { Yield } \\
\text { (\%) }\end{array}$ & E (\%) & $\begin{array}{c}\text { Yield } \\
\text { (\%) }\end{array}$ & E (\%) \\
\hline 30 & 24 & 15.7 & 21.74 & 32.4 & 44.86 & 23.4 & 32.4 \\
\hline & 48 & 21.9 & 30.32 & 43.8 & 60.65 & 39.0 & 54.0 \\
\hline & 72 & 22.2 & 30.74 & 44.5 & 61.62 & 40.4 & 55.94 \\
\hline 50 & 24 & 12.3 & 17.03 & 27.9 & 38.63 & 20.1 & 27.83 \\
\hline & 48 & 15.9 & 22.02 & 38.6 & 53.45 & 28.9 & 40.02 \\
\hline 70 & 72 & 19.8 & 27.42 & 38.9 & 53.86 & 30.9 & 42.78 \\
\hline & 24 & 8.5 & 11.77 & 10.5 & 14.54 & 8.6 & 11.91 \\
\hline & 48 & 10.2 & 14.12 & 10.9 & 15.09 & 9.4 & 13.02 \\
\hline
\end{tabular}

Table 5 Fourier Transform Infrared (FTIR) Characterization of Pure Glucose

\begin{tabular}{|c|c|c|l|}
\hline Serial No & Frequency (cm-1) & Peak Area & \multicolumn{1}{|c|}{ Assigned functional Group } \\
\hline 1 & 686.7681 & 0.2967709 & Meta disubstituted aromatic \\
\hline 2 & 790.2341 & 0.2970884 & Para disubstituted aromatic \\
\hline 3 & 880.1656 & 0.346344 & Geminaldisubstituted alkene \\
\hline 4 & 1073.869 & 0.694572 & Alkoxy C-O \\
\hline 5 & 1330.733 & 0.464741 & Nitro symmetric group N=0 \\
\hline 6 & 1608.217 & 0.5667408 & Nitro asymmetric group N=0 \\
\hline
\end{tabular}


International Journal of Frontiers in Engineering and Technology Research, 2021, 01(01), 061-069

\begin{tabular}{|c|c|c|l|}
\hline 7 & 1862.701 & 0.354259 & Ketones group C=O \\
\hline 8 & 2058.185 & 0.3656095 & Alkene C-H bend region \\
\hline 9 & 2144.022 & 0.4011851 & Aromatic group \\
\hline 10 & 2246.856 & 0.407736 & Acyl, strong C-O \\
\hline 11 & 2454.593 & 0.7394771 & Acid O-H, very broad (overlap C-H stretch) \\
\hline 12 & 2515.718 & 0.7147146 & Thio group S-H \\
\hline 13 & 2665.982 & 0.5441699 & Thio group S-H \\
\hline 14 & 2856.719 & 0.526873 & aldehyde C-H stretch (two bands) \\
\hline 15 & 2986.8 & 0.49722 & Alkene group C-H stretch \\
\hline 16 & 3123.093 & 0.6279666 & Alkene group C-H bend \\
\hline 17 & 3215.532 & 0.689305 & Amides strong NH2 (two bands) \\
\hline 18 & 3356.835 & 0.7904052 & Amides weak N-H (one band) \\
\hline 19 & 3,616 & 1.153365 & alcohol O-H stretch \\
\hline 20 & 3798.235 & 1.010345 & alcohol O-H stretch \\
\hline
\end{tabular}

Table 6 Fourier Transform Infrared (FTIR) characterization of Glucose from Cocoyam peel

\begin{tabular}{|c|c|c|l|}
\hline Serial No & Frequency (cm-1) & Peak Area & Assigned functional Group \\
\hline 1 & 708.8468 & 0.3298843 & Meta disubstituted aromatic \\
\hline 2 & 881.0667 & 0.3106069 & Geminaldisubstituted alkene \\
\hline 3 & 1064.352 & 0.7379492 & Alkoxy C-O \\
\hline 4 & 1229.854 & 0.5999861 & Acid C- O (acyl, strong) \\
\hline 5 & 1396.559 & 0.4440224 & Alkanes C-H bend \\
\hline 6 & 1624.1 & 0.8195098 & Amides N-H bend Stronger than Amines \\
\hline 7 & 1783.406 & 0.4915262 & Ketones group C=O \\
\hline 8 & 1863.412 & 0.4766571 & Anhydrides group C=O \\
\hline 9 & 2000.229 & 0.3603461 & Aromatics C-H bend (weak overtone) \\
\hline 10 & 2123.247 & 0.4286211 & Acid C- O (acyl, strong) \\
\hline 11 & 22223.606 & 0.5377615 & Acid C- O (acyl, strong) \\
\hline 12 & 2459.971 & 0.5180169 & Acids O-H very broad, (overlap C-H stretch) \\
\hline 13 & 2742.079 & 0.376213 & Aldehydes C-H weak \\
\hline 14 & 2952.291 & 0.5454173 & Alkanes C-H Stretch \\
\hline 15 & 3133.967 & 0.7419297 & Aromatics C-H Stretch \\
\hline 16 & 3301.147 & 0.8750531 & Alkene group C-H Stretch \\
\hline 17 & 3441.368 & 0.8156928 & Amides weak N-H (one band) \\
\hline 18 & 3680.039 & 1.364788 & alcohol O-H stretch \\
\hline 19 & 3,806 & 1.08593 & alcohol O-H stretch \\
\hline
\end{tabular}




\section{Conclusion}

The hydrolysis of ground cocoyam peels with $\mathrm{HCl}$ and $\mathrm{H}_{2} \mathrm{SO}_{4}$ at different temperatures, time and concentrations gave a maximum glucose yield of $27.3 \%$ and $26.5 \%$ respectively at $70^{\circ} \mathrm{C}, 180$ minutes and $5 \%$ acid concentration. Also in enzymatic hydrolysis, a maximum glucose yield of $44.5 \%$ was obtained at $30^{\circ} \mathrm{C}$, pH 5 and 3 days. Furthermore, the functional groups present in the cocoyam peel glucose and the standard glucose was evaluated using FTIR. The FTIR results showed similarities in the functional groups present in both sugars as shown in Tables 3.5 and 3.6.

Finally, the results obtained in this study have shown the suitability of cocoyam peel for the production of fermentable sugar that can be fermented to synthesize ethanol (biofuel).

\section{Compliance with ethical standards}

\section{Disclosure of conflict of interest}

No conflict of interest.

\section{References}

[1] Aberuagba F. The kinetics of acid hydrolysis of wastes cellulose from maize cobs and groundnut shells. Proceedings of the 27th annual conference of the Nigerian Society of chemical Engineers. 1997; 15-18.

[2] Akida M, Ratna N, Siti SS, Wahyudi BS. "Kinetics of Enzymatic Hydrolysis of Cellulose Using Aspergillusniger" Advanced Materials Research. 2015; 1101: 294-298.

[3] Barnard G, kristoferson L. Agricultural residues as fuel in the third World. Earth Scan Technical, No 4, International Institute for Environment and Development, London. 1983; 11 - 16.

[4] Benkun QJ, Xiangrong C, Fei S, Yi S, Yinhua W. Optimization of enzymatic hydrolysis of wheat straw pretreated by alkaline peroxide using response surface methodology Ind. Eng. Chem. Res. 2009; 48: 7346-7353.

[5] Enweremadu CC, Ojediran JO, Ogunwa A, Afolabi LO. Determination of the energy potentials of orange pomace. Science focus. 2004; 8: 5 - 9 .

[6] Fang H, Chen Z, Xiang-Yang S. Optimization of enzymatic hydrolysis of steam-exploded corn stover by two approaches: Response surface methodology or using cellulase from mixed cultures of Trichodermareesei RUTC30 and Aspergillus Niger NL02" Bioresource Technology. 2010; 101: 4111-4119.

[7] Gautem SP, Bundela PS, Pandey AK, Jamaluddin Khan M, K Awasthi, Sarsaiya S. Optimization for the Production of Cellulase Enzyme for Municipal Solid Waste Residue by Two Novel Cellulolytic Fungi. Biotechnology Research International. 2011; 8.

[8] Ghose TK. Cellulose biosynthesis and hydrolysis of cellulosic substances.Advances in Biochem. Eng. 6:3976.Handwerki, Brain. (2005). Egypt's “King Tut Curse” caused by Tom Toxins? Nation Geographic. 1956.

[9] Hussain M, Norton G, Neale RJ. Composition and nutritive value of cornmeal of Colocasiaesculenta (L) Shott", Journal of the Science of Food and Agriculture. 1984; 35: 1112-1119.

[10] Ihekoronye AI, Ngoddy PO. “Cocoyams”, in Integrated Food Science Technology fot the Tropics, pp. 280-281, Macmillian, London, UK. 1985.

[11] Iwuoha CI, Kalu FA. "Calcium Oxalate and Physi-Chemical properties of cocoyam (Colocasiaesculenta and XanthosomaSgittifolium) tuber flours as affected by processing”, Food Chemistry. 1985; 54: 61-66.

[12] John RP, Nampoothiri KM, Panday A. Fermentative production of lactic acid from biomass an overview on process development and future perspertives. ApplMicrobiol. Biotechnol. 2007; 74: 524.

[13] Kelly J. Dussán, Débora DV Silva, Elisângela JC Moraes, Priscila V Arruda, Maria GA Felipe. Dilute-acid Hydrolysis of Cellulose to Glucose from Sugarcane Bagasse" Chemical Engineering Transactions. 2014; 38.

[14] Lenihan PA, Orozco E, O’Neill MNM, Ahmad DW, Rooney GM, Walker. Dilute acid hydrolysis of lignocellulosic biomass" Chemical Engineering Journal. 2010; 156: 395-403.

[15] Lisa GA, APCBEES Chooi, H Chan, Chew AL. Enzymatic Hydrolysis of Rice Straw: Process Optimization" Journal of Medical and Bioengineering (JOMB). 2012; 1. 
[16] Mandels M. Applications of cellulases. Biochemical Society Transactions. 2005; 13: 414- 416.

[17] Miller GL. Use of dinitrosalicylic acid reagent for determination of reducing sugar, Anal.Chem. 1959; 31: 426.

[18] Nermeen A El-Sersy, Hanan Abd-Elnaby, Gehan M Abou-Elela, Hassan NAH Ibrahim, Nabil MK El-Toukhy. Optimization, economization and characterization of cellulase produced by marine streptomyces ruber. African Journal of Biotechnology. 2010; 9 (38), 6355-6364.

[19] Obiechina OC, Ajala AA. Socioeconomic and Cultural Importance of Cocoyam as a staple food, In processing of the !st National workshop on Cocoyam (NRCRI'87). 1985; 180-184.

[20] Obot IB, Israel AU, Umoren SA, Mkpenie V, Asuquo JE. Production of cellulosic polymers from agricultural wastes. E. Journal of Chemistry. 2010; 5(1): 81-85.

[21] Omojasola PF, Jilani OP. Cellulase Production by Trichodermalongi, Aspergillus Niger and Saccharomyces cerevisae Cultured on Plantain Peel. Research Journal of Microbiology. 2009; 4: 67-74.

[22] Onwueme CI. "Colocasia and Xanthosoma", in the Tropical Tuber Crops, pp. 199-227, John Wiley and Sons, New York, NY USA. 1978.

[23] Onwueme IC. The Tropical Tuber Crops, English Language Book Society, John Wiley and Sons, Chichester, UK. 1982.

[24] Purseglove JW. “Araceae”, in Tropical Crops: Monocotyledons PP. 58 - 74, Longman, Essex, UK, Irvine, F.R. (1969). “Cocoyam" West African Crops PP. 74 - 179 Oxford University Press, Oxford, UK. 1972.

[25] Searchinger T, Heimlich R, Houghton RA, Dong F, Elobeid A, Fabiosa J, Tokgoz S, Hayes D, Tung-Hsaing JY. Use of U.S, croplands for biofuels increase greenhouse gases through emission from land-use change Science. 2008; 319: 1238-1240.

[26] Soltoes EJ. Thermo-chemical routes to chemicals, fuels and energy from forestry and agricultural residues. In: W.A. Cote, Biomass Utilization, Plenum Press, New York. 1983; 23 - 47.

[27] Xavier MR. The sugarcane ethanol experience.Issues Analysis No.3. Competitive Enterprise Institute, Washington, DC. 2007.

[28] Ye S, Cheng J. Hydrolysis of lignocellulosic materiาals for ethanol production: a review. Bioresour. Technol. 2002; 83: 1-11. 